JPT: Jurnal Proteksi Tanaman (Journal of Plant Protection)

ISSN : 2580-0604

Online ISSN: 2621-3141
Vol 4 No.1 (2020): $45-51$

Website:http://jpt.faperta.unand.ac.id/index.php/jpt

\title{
Pengaruh Lama Penyimpanan Ekstrak Kasar Daun Mahkota Dewa (Phaleria macrocarpa) terhadap Mortalitas Keong Mas (Pomacea canaliculata)
}

\author{
Effect of Storage Time of Mahkota Dewa Leaf Crude Extract (Phaleria macrocarpa) on \\ Mortality of Golden Snail (Pomacea canaliculata) \\ Rusdi Rusli ${ }^{1)^{*}}$, Winarto $^{1)}$, Jogi Aprihan Putra ${ }^{2)}$ \\ 1) Program Studi Proteksi Tanaman, Fakultas Pertanian Universitas Andalas, Padang \\ 2) Program Studi Agroteknologi, Fakultas Pertanian Universitas Andalas, Padang \\ E-mail : Rusdi.rusli46@gmail.com \\ Diterima: 03 Mei 2020 Disetujui: 29 Juni 2020 Dipublikasi: 30 Juni 2020
}

\begin{abstract}
Mahkota dewa [Phaleria macrocarpa (Scheff) Boerl] contains saponin that can be used as a botanical pesticide, including molluscicide. This study aimed to obtain the most effective storage time of leaf crude extract of mahkota dewa on the mortality of golden snail. The application was carried out in the greenhouse of Faculty of Agriculture of Universitas Andalas from March to May 2019. The study used a Randomized Block Design (RBD) consisting of time of storage, i.e., 0 day ( 2 hours), two days, four days, six days, and eight days those were applied to early-stage, late-stage, male and female of golden snail. The results showed that all storage time of mahkota dewa leaf crude extract had the same effect on early state golden snail mortality. However, at late state golden snail 0 day and two days, storage times were the best. Two days of storage time caused mortality of early-stage, late-stage, and male adult of the golden snail, however, 0 days ( 2 hours) for female adult.
\end{abstract}

Keywords: Mahkota dewa, golden snail, storage time

\section{PENDAHULUAN}

Keong mas (Pomacea canaliculata Lamarck) merupakan salah satu jenis hewan dari filum Mollusca, keberadaannya sering ditemukan di sawah, parit, rawa dan saluran irigasi. Pada saat lahan dalam keadaan kering, keong mas masih dapat bertahan hidup dalam tanah hingga waktu 6 bulan (Basri, 2010). Keong mas merusak tanaman padi mulai dari persemaian sampai berumur di bawah 4 minggu setelah tanam. Keong mas menyerang tanaman padi dengan cara memotong pangkal batang padi muda yang menyebabkan rumpun padi rusak dan mati (Yunidawati et al., 2011). Keong mas selama hidupnya mampu menghasilkan telur sebanyak 1520 kelompok, setiap kelompok berjumlah \pm 500 butir dengan persentase penetasan lebih dari 85\% (Rusdy, 2010).

Menurut Sulistyanto (2006), keong mas merupakan hewan herbivora yang sangat berbahaya karena menyrang tanaman padi muda sehingga menghambat pembentukan rumpun, selain itu juga menyerang daun sehingga daun menjadi berlubang dan terdapat jalur-jalur bekas lendir yang menyebabkan gugurnya daun. Keong mas merusak tanaman padi dengan intensitas serangan sebesar 13,2\% hingga 96,5\% (Suharto dan Kurniawati, 
2009). Hasil penelitian Rifa'i (2004) menunjukkan bahwa populasi keong mas sebanyak 4-8 pasang $/ \mathrm{m}^{2}$ menyebabkan intensitas serangan mencapai $60 \%$ pada hari pertama, selanjutnya intensitas serangan mencapai $100 \%$ pada hari ke- 8 ditandai dengan habisnya anakan padi. Sampai sekarang belum ditemukan tanaman padi yang tahan terhadap serangan keong mas ini (Rusli et al., 2018).

Keong emas merupakan hama yang sulit diberantas karena kemampuan ber-adaptasi yang tinggi sehingga bisa hidup di berbagai jenis habitat. Selain itu, daya reproduksi keong mas tinggi yang ditandai dengan jumlah telur mencapai \pm 8700 butir per musim reproduksi dan mampu bertahan dalam kondisi lingkungan yang kering. Hal ini menjadi alasan melimpahnya populasi keong mas di sawah (Yusa et al., 2006). Penanganan keong mas di Indonesia sudah dilakukan dengan berbagai cara, diantaranya dengan pengumpulan telur, pemberian umpan, penggunaan musuh alami seperti menggunakan bebek, pestisida nabati dan penggunaan pestisida kimia (moluskisida sintetik) (Budiyono, 2006). Menurut Gassa, 2011), moluskisida sintetik selain harganya yang mahal, umumnya juga berspektrum luas sehingga dapat menimbulkan dampak negatif terhadap organisme yang bukan sasaran, selain itu juga dapat menyebabkan keracunan pada petani atau ternak peliharaan. Untuk mengurangi dampak yang ditimbulkan oleh moluskisida sintetik dapat dilakukan cara alternatif pengendalian yaitu dengan pemanfaatan pestisida nabati (Kardinan, 2002).

Pestisida nabati yang bahan utamanya berasal dari tumbuhan, seperti akar, daun, batang atau buah dapat berperan sebagai antifeedant, pengatur pertumbuhan hama, dan pencegah oviposisi (Trisnadi, 2016). Pestisida nabati yang berasal dari tumbuhan umumnya mem- punyai karakteristik rasa pahit (mengandung saponin, alkaloid dan terpen), berbau busuk dan berasa agak pedas. Tumbuhan seperti ini jarang diserang oleh hama sehingga banyak digunakan sebagai pestisida nabati (Hasyim et al., 2010). Diantara pestisida nabati yang efektif mengendalikan keong mas adalah ektrak kasar daun tanaman mangkokan dan mahkota dewa (Rusli et al., 2019).

Beberapa penelitian melaporkan bahwa penggunaan daun mangkokan (Polyscias scutellaria) yang disimpan selama 1 malam efektif dalam menekan populasi keong mas sebesar $80 \%$ (Efendi, 2001). Ekstrak daun sukun berpotensi sebagai moluskisida nabati karena dapat mematikan semua keong mas pada hari ketiga setelah perlakuan. Adanya lendir pada tubuh keong mas yang mati menunjukkan gejala adanya keracunan saponin (Rastyawati, 2015). Ekstrak daun mahkota dewa (Phaleria macrocarpa (Scheff) Boerl) efektif meningkatkan mortalitas keong mas sehingga mencapai $100 \%$ pada konsentrasi $10 \mathrm{~g} / \mathrm{l}$ dengan waktu 3 hari pemaparan, sedangkan konsentrasi $25 \mathrm{~g} / \mathrm{l}$ dapat meningkatkan mortalitas keong mas mencapai $100 \%$ pada waktu 2 hari dan 3 hari pemaparan (Nailirrahma, 2014).

Lebih lanjut, penyimpanan air rebusan daun mangkokan 3 dan 5 hari masih efektif karena menyebabkan mortalitas keong mas mencapai $100 \%$ pada hari ketiga (72 jam). Menurut Nailirrahma (2014), daun mahkota dewa mengandung senyawa aktif yang bersifat moluskisida yaitu saponin, sehingga daun ini mempunyai potensi untuk dikembangkan sebagai moluskisida nabati, namun belum diketahui lama penyimpanan yang paling efektif untuk pengendalian keong mas. Penelitian ini bertujuan untuk mengetahui pengaruh lama penyimpanan pestisida nabati yang dibuat dari ekstrak kasar daun mahkota dewa terhadap keong mas. 


\section{METODOLOGI}

Penelitian ini dilaksanakan pada bulan Maret sampai bulan Mei 2019 di Rumah Kaca Fakultas Pertanian Universitas Andalas Padang.

\section{Metode}

Penelitian ini menggunakan Rancangan Acak Kelompok (RAK) yang terdiri dari 6 perlakuan dan 4 ulangan. Perlakuan tersebut berupa lama penyimpanan ekstrak daun mahkota dewa selama 0 hari ( 2 jam), 2 hari, 4 hari, 6 hari, 8 hari dan kontrol. Penelitian ini dilaksanakan dalam 4 tahap penelitian yaitu pengamatan mortalitas keong mas stadia awal, stadia lanjut, jantan, dan betina.

\section{Pelaksanaan penelitian \\ Penyediaan wadah uji tempat perlakuan}

Wadah uji yang digunakan yaitu baskom plastik bulat dengan diameter 40 $\mathrm{cm}$ dan tinggi $15 \mathrm{~cm}$, kemudian wadah uji diisi dengan lumpur setinggi $3 \mathrm{~cm}$ dan ditambahkan air sebanyak 2,5 liter (tinggi air $3 \mathrm{~cm}$ ).

\section{Pengadaan keong mas}

Keong mas didapatkan dari lokasi sekitar persawahan. Keong mas yang digunakan untuk 4 tahap penelitian tersebut adalah stadia pertumbuhan awal dengan panjang cangkang $5 \mathrm{~mm}$, stadia pertumbuhan lanjut dengan panjang cangkang 2 $\mathrm{cm}$, keong mas jantan dan betina dengan panjang cangkang $2,5-3,5 \mathrm{~cm}$.

\section{Pengadaan pestisida nabati}

Daun mahkota dewa diambil di daerah Limau Manis Kota Padang. Daun tersebut dicuci bersih, kemudian ditimbang sebanyak $5 \mathrm{~g}$, selanjutnya dipotong kecil-kecil dan dimasukkan ke dalam 1 liter air untuk dihancurkan dengan menggunakan blender selama \pm 5 menit. Ekstrak kasar dimasukkan ke dalam ember untuk disimpan. Ektrak perlakuan yang digunakan terlebih dahulu adalah yang disimpan 8 hari, setelah dua hari berikut- nya untuk 6 hari, dan seterusnya sampai perlakuan penyimpanan 0 hari ( 2 jam).

\section{Infestasi keong mas dan aplikasi pestisida} nabati

Sebanyak 10 ekor keong mas uji sesuai tahapan (stadia awal, stadia lanjut, jantan dan betina) diinfestasikan dalam masing-masing wadah uji yang telah diisi lumpur dan air, kemudian sebanyak $50 \mathrm{~g}$ daun kangkung dimasukkan sebagai bahan makanan, dilanjutkan dengan memasukkan sebanyak 1 liter ekstrak kasar daun mahkota dewa. Pemberian ekstrak kasar mahkota dewa dengan cara dituangkan ke dalam wadah uji dan dilakukan pada sore hari dengan tujuan menghindari agar pestisida tidak terurai oleh cahaya matahari.

\section{Pengamatan}

\section{Mortalitas keong mas (\%)}

Pengamatan keong mas yang mati dilakukan tiap sore hari selama 3 hari. Penghitungan keong mas yang mati dilakukan dengan cara mengeluarkan keong mas dari wadah uji, lalu keong yang mati dihitung jumlahnya. Keong mas yang belum dapat dipastikan hidup atau mati (keong masih dalam cangkang) dikeluarkan dari wadah uji kemudian dimasukkan kembali ke wadah berisi makanan dan ditunggu respons keong selama \pm 5-15 menit. Jika keong belum keluar dari cangkang, maka tubuhnya ditekan dengan tusuk gigi secara perlahan, untuk memastikan keong tersebut mati atau hidup seperti yang dilakukan Wardhani (2011). Mortalitas dihitung dengan rumus:

$\mathrm{M}=\frac{n}{N} \times 100 \%$

Keterangan :

$\mathrm{M}=$ Mortalitas keong mas

$\mathrm{n}=$ Jumlah individu keong mas yang mati

$\mathrm{N}=$ Jumlah individu keong mas seluruhnya

\section{Analisis data}

Data yang diperoleh dari hasil pengamatan dianalisis dengan sidik ragam, dilanjutkan dengan uji lanjut Dun- 
can's New Multiple Range Test (DNMRT) pada taraf nyata $5 \%$.

\section{HASIL}

\section{Mortalitas keong mas (\%)}

Ekstrak kasar daun mahkota dewa secara umum telah menyebakan kematian terhadap keong mas dari stadia awal, stadia lanjut, jantan dan betina. Lama penyimpanan ekstrak tidak mempengaruhi mortalitas keong mas stadia awal, tetapi cenderung menurunkan mortalitas keong mas stadia lanjut, penurunan terutama terjadi pada penyimpanan ekstrak 6 dan 8 hari. Lama penyimpanan yang paling baik untuk mengendalikan keong mas stadia lanjut adalah 0-2 hari. Lama penyimpanan juga tidak berpengaruh terhadap mortalitas keong mas jantan, tetapi lama penyimpanan berpengaruh terhadap mortalitas keong mas betina. Lama penyimpanan menurunkan mortalitas keong mas betina secara signifikan. Penyimpanan ekstrak kasar daun mahkota dewa dapat menyebabkan mortalitas keong mas jantan mencapai $85 \%$, sedangkan aplikasi langsung tanpa penyimpanan dapat menyebabkan mortalitas keong mas betina mencapai 85\% (Tabel 1).

Tabel 1. Mortalitas kumulatif keong mas dari berbagai stadia setelah diperlakukan dengan ekstrak kasar daun mahkota dewa pada hari ke-3 setelah perlakuan

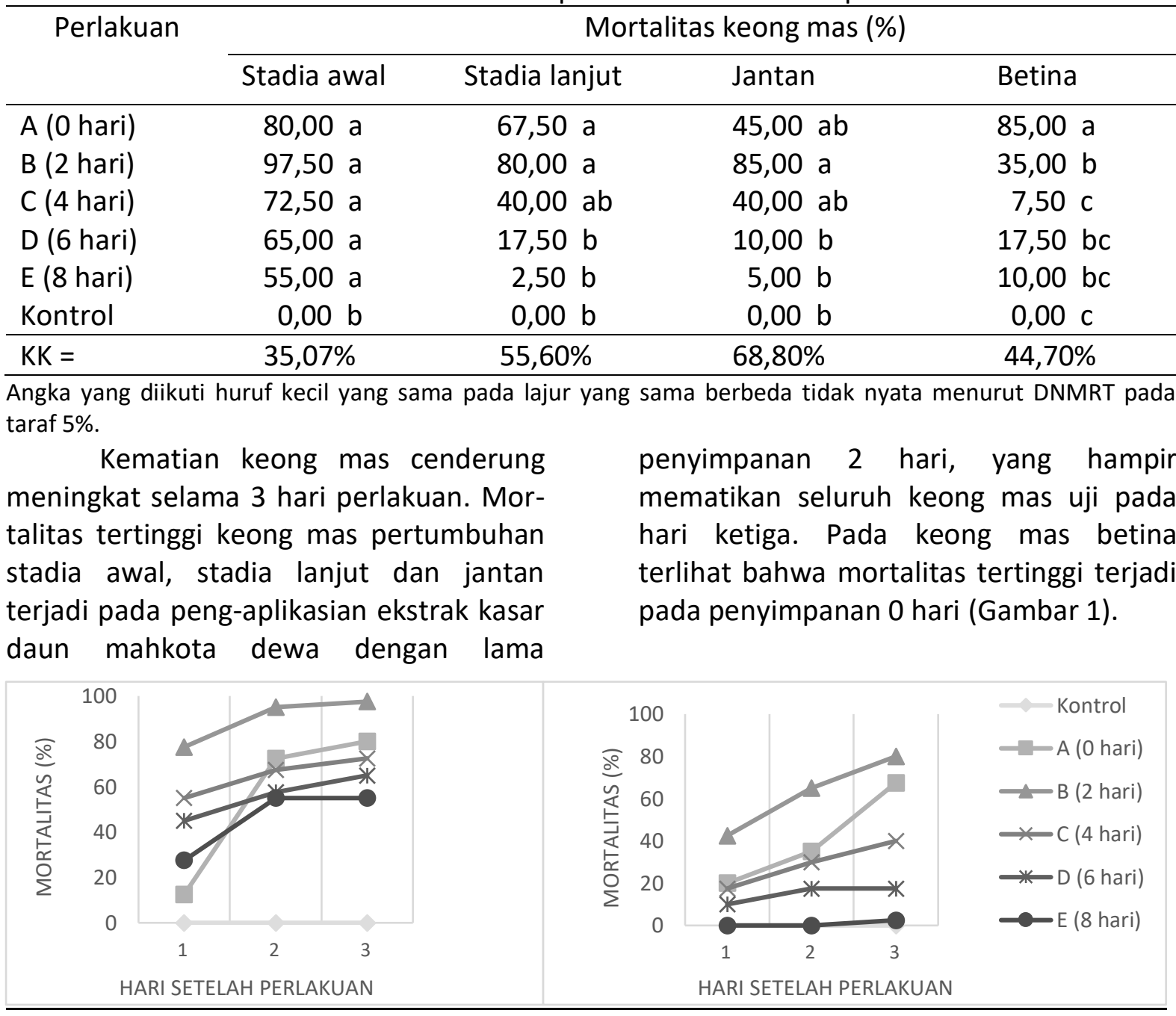

(a)

(b) 
Rusli et al., Pengaruh Lama Penyimpanan Ekstrak Kasar Daun Mahkota Dewa

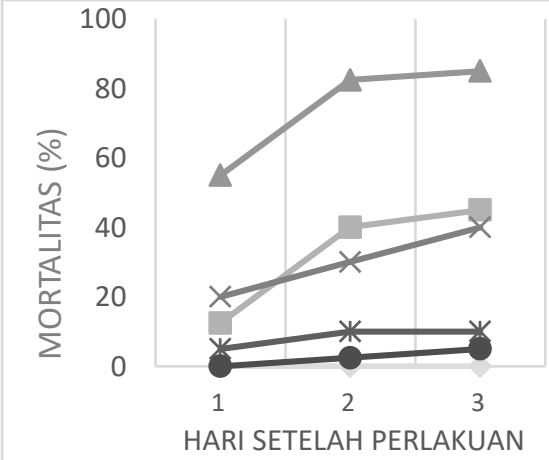

(c)

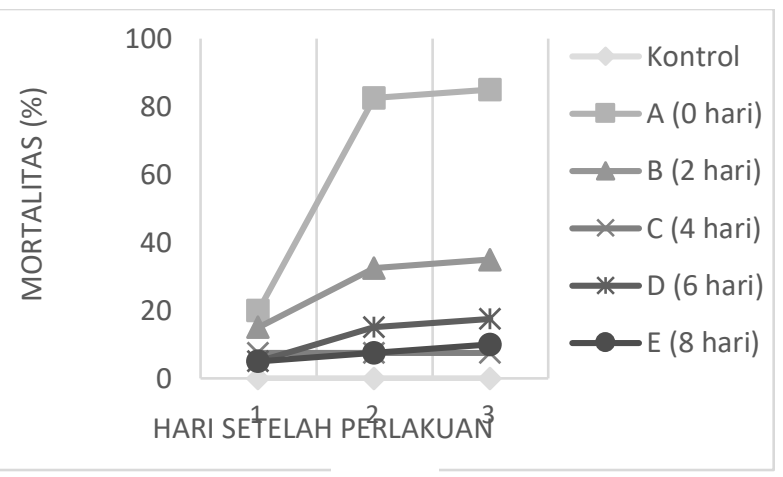

(d)

Gambar 1. Mortalitas kumulatif keong mas pada berbagai stadia: a. stadia awal, stadia lanjut, c. jantan, d. betina

\section{PEMBAHASAN}

Aplikasi ekstrak daun mahkota dewa telah menyebabkan kematian terhadap keong mas pada stadia awal, lanjut, jantan dan betina. Hal ini diduga karena keong mas keracunan senyawa saponin ekstrak kasar daun mahkota dewa yang masuk ke dalam tubuh keong mas. Hal ini sesuai dengan hasil penelitian Wardhani (2011) bahwa kandungan saponin menyebabkan kematian pada keong mas, baik cara penyerapan langsung melalui kulit keong mas maupun pengambilan air melalui membran insang. Menurut Kurniawati et al. (2007), daging keong mas menjadi lunak karena terjadi proses saponifikasi. Menurut Musman (2011), keong mas bergerak mencari makan dengan cara membuka operkulumnya, keaktifan bergerak untuk mencari makan mengakibatkan terjadi kontak tubuh keong mas dengan ekstrak pestisida nabati, akibatnya ekstrak terakumulasi pada tubuh keong mas sehingga mengeluarkan lendir. Keluarnya lendir dari tubuh keong mas dalam jumlah yang berlebihan, menghambat proses pernafasan dan meng-akibatkan kematian. Hal lain juga di-duga karena keong mas memakan pakan yang sudah terkena ekstrak kasar daun mahk-ota dewa, sehingga senyawa tersebut ma-suk ke dalam tubuh keong mas melalui pakan tersebut.
Hasil penelitian menunjukan bahwa lama penyimpanan tidak mempengaruhi mortalitas keong mas secara signifikan (Tabel 1). Pada keong mas stadia awal didapatkan mortalitas paling banyak dibandingkan keong mas stadia lanjut, jantan dan betina (Tabel 1,2,3). Hal ini diduga karena keong mas stadia awal memiliki struktur cangkang dan operkulum yang belum sempurna sehing-ga senyawa kimia yang bersifat toksik yang terdapat pada ekstrak kasar daun mahkota dewa akan lebih mudah masuk ke dalam tubuh keong. Hal ini sesuai dengan pernyataan Susanto (1993) bahwa keong mas dalam masa pertumbuhan awal mempunyai cangkang dan operkulum yang sangat tipis dan transparan dan belum berkembang secara sempurna sehingga mudah ditembus oleh ekstrak tersebut.

Mortalitas tertinggi terjadi pada penyimpanan 2 hari yang hampir mematikan seluruh keong mas lanjut dan jantan pada hari ketiga pengamatan (Tabel 1). Hal ini diduga karena pada penyimpanan 2 hari belum menyebabkan penguraian bahan aktif yang terdapat pada ekstrak daun mahkota dewa oleh enzim pengurai dibandingkan dengan penyimpanan 4 hari ke atas. Semakin lama penyimpanan semakin menurunkan mortalitas hama. Prijono (1999) menyatakan bahwa insektisida nabati yang disimpan dan terdedah di lapa- 
ngan sangat mudah terdegradasi sehingga menurunkan keefektifannya.

Penyimpanan 0 hari ( 2 jam) memperlihatkan terjadinya peningkatan mortalitas yang signifikan pada hari kedua (Gambar 1). Hal ini diduga pada hari pertama keong mas mengalami keracunan saponin dari ekstrak kasar daun mahkota dewa, kemampuan makannya menjadi berkurang dan tidak aktif bergerak, sehingga pada hari kedua terjadi peningkatan yang signifikan terhadap mortalitas keong mas. Toksisitas dari ekstrak kasar daun mahkota dewa tidak mematikan keong mas secara langsung. Menurut Gotama et al. (1999) bahwa daun mahkota dewa yang mengandung saponin, ditandai dengan adanya gejala keracunan seperti sekresi lendir, tubuh menjadi lunak, kemampuan makan menurun, aktivitas hidup rendah, operkulum menutup semakin rapat dan kemudian mengalami kematian. Gejala yang terjadi pada keong mas yang mengalami kematian yaitu tubuh keong mas menjadi kaku, cangkang menjadi rapuh, operkulum terbuka, tubuh keluar dari cangkang dan semakin lama meninggalkan bau tidak sedap (Naillirrahma, 2014).

Penyimpanan 0 hari menurunkan mortalitas keong mas betina secara signifikan. Penyimpanan 2 hari lebih baik dibandingkan 4 hari, tetapi tidak berbeda dengan penyimpanan 6 hari dan 8 hari (Tabel 1). Hal ini diduga karena ekstrak kasar daun mahkota dewa sebagai pestisida nabati tidak tahan disimpan lama dan semakin lama disimpan maka toksisitas akan menurun. Hendayana (2006) menyatakan kelemahan pestisida nabati antara lain: 1) daya kerja relatif lambat, 2) tidak membunuh jasad secara langsung, 3) tidak tahan disimpan dalam waktu yang lama.

\section{KESIMPULAN}

Lama penyimpanan ekstrak kasar daun mahkota dewa dari 0-8 hari menyebabkan kematian yang tinggi terhadap keong mas pada stadia awal, akan tetapi lama penyimpanan 0-2 hari paling baik mengendalikan keong mas stadia lanjut. Mortalitas tertinggi terjadi pada penyimpanan selama 2 hari yang paling tinggi mematikan keong mas stadia awal, stadia lanjut dan jantan, sedangkan untuk pengendalian keong mas betina disarankan mengaplikasikan ekstrak kasar daun mahkota dewa secara langsung tanpa panyimpanan.

\section{DAFTAR PUSTAKA}

Basri AB. 2010. Pengendalian dan pemanfaatan keong mas. Serambi Pertanian. Jakarta.

Budiyono S. 2006. Teknik pengendalian keong mas pada tanaman padi. Jurnal IImu-IImu Pertanian 2(2): 128133.

Efendi E. 2001. Pengujian beberapa jenis tumbuhan dalam menekan populasi keong mas (Pomaceae spp.) pada padi sawah. Skripsi. Universitas Andalas. Padang.

Gassa A. 2011. Pengaruh buah pinang (Areca catechu) terhadap mortalitas keong mas (Pomacea canaliculata) pada berbagai stadia. Jurnal Fitomedika 7(3): 171-174.

Gotama IBI, S Sugiarto, M Nurhadi, Y Widiyastuti, S Wahyono dan IJ Prapti. 1999. Inventaris tanaman obat Indonesia Jilid V. Departemen Kesehatan Badan Penelitian dan Pengembangan Kesehatan. Jakarta.

Hasyim A, W Setiawati, B Murtiningsih dan E Sofiari. 2010. Efikasi dan persistensi minyak serai sebagai biopestisida terhadap Helicoverpa armigera Hubn. (Lepidoptera: Noctuidae). Jurnal Hortikultura 20(4): 377-386. 
Kardinan A. 2002. Pestisida nabati, ramuan dan aplikasi. Penebar Swadaya. Jakarta.

Kurniawati. 2007. Keong mas dari hewan peliharaan menjadi hama utama tanaman padi. Depertemen Pertanian. Jakarta.

Musman M. 2011. Uji selektivitas ekstrak etil asetat (EtOAc) biji putat air (Barringtonia racemosa) terhadap keong mas (Pomacea canaliculata) dan ikan lele lokal (Clarias batrachus). Depik 1(1): 27-31.

Nailirrahma. 2014. Efektivitas ekstrak daun mahkota dewa dan daun mengkudu sebagai moluskisida nabati terhadap daya hidup keong mas (Pomacea canaliculata Lamarck). Skripsi. Institut Pertanian Bogor. Bogor.

Prijono D. 1999. Prospek dan strategi pemanfaatan insektisida nabati dalam PHT. Dalam Nugroho BW, Dadang dan Prijono D (Eds.). Bahan Pelatihan Pengembangan dan Pemanfaatan Insektisida Nabati. Pusat Kajian Pengendalian Hama Terpadu. Bogor.

Rastyawati. 2015. Efektivitas ekstrak daun nangka dan daun sukun sebagai moluskisida nabati terhadap daya hidup keong mas (Pomacea Canaliculata Lamarck). Skripsi. Institut Pertanian Bogor. Bogor.

Rifa'i A. 2004. Penentuan ambang kendali keong mas (Pomacea spp) pada tanaman padi sawah. Skripsi. Universitas Andalas. Padang.

Rusdy A. 2010. Pengaruh pemberian ekstrak bawang putih terhadap mortalitas keong mas. Jurnal Floratek 2(5): 172-180.

Rusli R, S Gani dan RT Hutasoit. 2018. Preferensi dan tingkat serangan keong mas (Pomaceae canaliculata Lamark) terhadap beberapa varietas padi (Oryza sativa Linnaeus). Jurnal Proteksi Tanaman 2(1): 1-8.

Rusli R, Martinius dan D Masduki. 2019. Efektifitas ekstrak beberapa tumbuhan untuk pengendalian keong mas (Pomaceae canaliculata Lamark) pada tanaman padi sawah. Jurnal Proteksi Tanaman 3(1): 1-9.

Suharto H dan N Kurniawati. 2009. Keong mas, dari hewan peliharaan menjadi hama utama padi sawah. Balai Besar Penelitian Tanaman Padi. Yogyakarta.

Sulistiyanto D. 2006. Kala nematoda pesta escargot. Trubus No. 435. Jakarta.

Susanto 1993. Siput Murbei. Kanisius. Jakarta.

Trisnadi R. 2016. Pestisida nabati ramah lingkungan untuk mengendalikan hama dan penyakit tanaman. Dinas Perkebunan dan Kehutanan. Pemerintah Kabupaten Probolinggo. Probolinggo.

Wardhani SPR. 2011. Daya hidup keong mas (Pomacea canaliculata Lamarck) setelah terpapar ekstrak daun pepaya dan ekstrak daun sirih [Skripsi]. Institut Pertanian Bogor. Bogor.

Yunidawati W, B Darma, BJD Sengli. 2011. Penggunaan ekstrak biji pinang untuk mengendalikan hama keong mas (Pomacea canaliculata Lamarck) pada tanaman padi. Jurnal Ilmu Pertanian KULTIVAR 5(2): 84.

Yusa Y, N Sugiura and T Wada. 2006. Predatory potential of freshwater animals on an invasive agicultural pest, the apple snail Pomacea canaliculata (Gastropoda: Ampullariidae), in Southern Japan. Japan. Biological Invasions 8(2): 137-147. 